\title{
1 Demand for hospitalization services for COVID-19 patients in Brazil
}

3 Marcia C. Castro, $\mathrm{PhD}^{1}$, Lucas Resende de Carvalho, MS, ${ }^{2}$ Taylor Chin, $\mathrm{MS},{ }^{3}$ Rebecca Kahn,

4 MS, ${ }^{3}$ Giovanny V. A. França, $\mathrm{PhD}^{4}$, Eduardo Marques Macário, $\mathrm{PhD}^{4}$, Wanderson Kleber de

$5 \quad$ Oliveira, $\mathrm{PhD}^{4}$

$7 \quad{ }^{1}$ Harvard T.H. Chan School of Public Health, Department of Global Health and Population, 665

8 Huntington Avenue, Boston, MA 02115, United States of America

$9 \quad{ }^{2}$ Center for Development and Regional Planning, Federal University of Minas Gerais, Avenida

10 Presidente Antônio Carlos, 6627. Belo Horizonte, MG, 31270-901, Brazil

$11{ }^{3}$ Center for Communicable Disease Dynamics, Department of Epidemiology, Harvard T.H.

12 Chan School of Public Health, Boston, MA 02115, United States of America

$13{ }^{4}$ Secretariat of Health Surveillance, Brazilian Ministry of Health, Setor de Rádio e Televisão

14 Norte (SRTV) 701, Via W5 Norte, Edifício PO700. Brasília, Distrito Federal, 70719-040, Brazil 
medRxiv preprint doi: https://doi.org/10.1101/2020.03.30.20047662; this version posted April 1, 2020. The copyright holder for this preprint (which was not certified by peer review) is the author/funder, who has granted medRxiv a license to display the preprint in perpetuity.

All rights reserved. No reuse allowed without permission.

\section{Abstract}

17 COVID-19 is now a pandemic and many of the affected countries face severe shortages of

18 hospital resources. In Brazil, the first case was reported on February 26. As the number of cases

19 grows in the country, there is a concern that the health system may become overwhelmed,

20 resulting in shortages of hospital beds, intensive care unit beds, and mechanical ventilators. The

21 timing of shortage is likely to vary geographically depending on the observed onset and pace of

22 transmission observed, on the availability of resources, and on the actions implemented. Here we

23 consider the daily number of cases reported in municipalities in Brazil to simulate twelve

24 alternative scenarios of the likely timing of shortage, based on parameters consistently reported

25 for China and Italy, on rates of hospital occupancy for other health conditions observed in Brazil

26 in 2019, and on assumptions of allocation of patients in public and private facilities. Results

27 show that hospital services could start to experience shortages of hospital beds, ICU beds, and

28 ventilators in early April, the most critical situation observed for ICU beds. Increasing the

29 allocation of beds for COVID-19 (in lieu of other conditions) or temporarily placing all resources

30 under the administration of the state delays the anticipated start of shortages by a week. This

31 suggests that solutions adopted by the Brazilian government must aim at expanding the available

32 capacity (e.g., makeshift hospitals), and not simply prioritizing the allocation of available

33 resources to COVID-19. 
medRxiv preprint doi: https://doi.org/10.1101/2020.03.30.20047662; this version posted April 1, 2020. The copyright holder for this preprint (which was not certified by peer review) is the author/funder, who has granted medRxiv a license to display the preprint in perpetuity.

All rights reserved. No reuse allowed without permission.

\section{Introduction}

On March 11 the World Health Organization characterized COVID-19 as a pandemic. Caused by the novel coronavirus SARS-CoV-2, it emerged in China and quickly spread across the country and beyond. As of March 27, it was present in 202 countries and territories, with 509,164 cases and 23,335 deaths reported. ${ }^{1}$ The clinical course of COVID-19 poses serious challenges to the health system and may call for drastic rationing decisions. ${ }^{2,3}$ Specifically, allocating hospital

41 beds, intensive care unit (ICU) beds, and mechanical ventilators to COVID-19 patients, besides

42 the ongoing demand driven by other conditions, is a real or soon to be a real problem. ${ }^{4-6}$

43 Brazil recorded the first COVID-19 case on February 26 and the first death on March 17, both in 44 São Paulo. In 24 days, the disease had spread to every federal unit. As of March 27, 3,417 cases and 92 deaths had been reported. As the numbers increase across the country, so does the

46 demand for hospital services, raising concerns of hospital capacity to cope with that demand.

47 Brazil has a hybrid health system. ${ }^{7,8}$ On the one hand, every citizen has free access to the Unified

48 Health System (SUS). On the other hand, the private sector offers services covered by out of

49 pocket payments and private insurance plans. About $80 \%$ of the Brazilian population relies

50 solely on SUS, but this number varies widely across the country reflecting striking inequalities. ${ }^{9}$

51 The offer of hospital services is also unequal. As of December $2019,67 \%$ and $48 \%$ of the total

52 available hospital beds and ICU beds, respectively, were offered in the public system.

53 Geographically, the distribution was also unequal, with 9 and 21 beds per 100,000 people in the

54 North and Southeast regions, respectively. ${ }^{10}$

55 Here we address this concern and simulate the time it would take for hospitals to operate at 56 capacity, given the current trajectory of COVID-19 in Brazil. We considered different scenarios

57 of supply and demand and detailed the simulations by day and health macro-region. Since not all 
medRxiv preprint doi: https://doi.org/10.1101/2020.03.30.20047662; this version posted April 1, 2020. The copyright holder for this preprint (which was not certified by peer review) is the author/funder, who has granted medRxiv a license to display the preprint in perpetuity.

All rights reserved. No reuse allowed without permission.

58 services are available in each municipality, the Ministry of Health $(\mathrm{MoH})$ considers the macro-

59 region to guide the regionalization of health services.

\section{Methods}

\section{DATA SOURCES}

63 Population by age group and the number of confirmed COVID-19 cases were obtained from the

$64 \mathrm{MoH} .{ }^{11}$ Information on available hospital beds, ICU beds, and mechanical ventilators as of

65 December of 2019 was extracted from the National Registry of Health Establishments (CNES,

66 http://cnes.datasus.gov.br/). We excluded pediatric and obstetric beds, and pediatric, neonatal,

67 and burn recovery ICU beds. We distinguished hospital beds and ICU beds by type of service

68 (private and public); this classification was not available for mechanical ventilators. Average

69 public hospital occupancy in 2019 (detailed by hospital beds and ICU beds) was obtained from

70 the hospitalization system of the MoH (http://sihd.datasus.gov.br/). There was no information on

71 the occupancy rate for private hospitals (here we assumed the same rate obtained for public

72 hospitals). Lastly, access to private health insurance in December 2019 was extracted from the

73 Brazilian Regulatory Agency (http://www.ans.gov.br/perfil-do-setor/dados-e-indicadores-do-

74 setor).

77 We conducted forward simulations of the demand for hospital beds, ICU beds, and mechanical

78 ventilators by health macro-region in Brazil. In the initial phase of a new infectious disease

79 outbreak, the number of cases grows exponentially. ${ }^{12,13}$ Using the number of cases reported to 
medRxiv preprint doi: https://doi.org/10.1101/2020.03.30.20047662; this version posted April 1, 2020. The copyright holder for this preprint (which was not certified by peer review) is the author/funder, who has granted medRxiv a license to display the preprint in perpetuity.

All rights reserved. No reuse allowed without permission.

80 date and estimates of doubling times from the outbreak in China, ${ }^{14-16}$ we estimated the number of

81 future cases each day. As the outbreak spreads, the exponential model becomes less realistic, ${ }^{13}$ so

82 we stopped the simulations once $10 \%$ of the population was estimated to be infected.

83 We used the age structure of each macro-region combined with age-specific attack and severity

84 rates drawn from the literature. We used attack rates by age from the outbreak in China, ${ }^{17}$

85 considering a range of $\pm 3 \%$, and considered that $86 \%$ of all infections were undocumented. ${ }^{18}$

86 Demand for hospitalization was calculated using the severity of cases by age from China. ${ }^{17}$ Time

87 from illness to hospitalization was 3-7 days, ${ }^{19,20}$ and length of hospitalization ranged from 7-15

88 days, ${ }^{21}$ for ICU hospitalizations these parameters were $8-15,{ }^{19,20}$ and $7-15,{ }^{21,22}$ respectively. We

89 considered that $5 \%$ of the cases needed ICU admission ${ }^{21,23}$ and half of those in ICU needed

90 mechanical ventilation ${ }^{20,21}$ for an average of 5 days. ${ }^{24}$ We also simulated an alternative scenario

91 based on Italy and assumed that $12 \%$ of the cases needed ICU admission. ${ }^{4,6}$ These parameters

92 were combined with assumptions of hospital occupancy and type of service to produce twelve

93 scenarios, summarized in Table 1. We performed 1,000 runs for each scenario, drawing from the

$94 \pm 3 \%$ uncertainty around attack rates, and considered the results that represented the median of

95 the distribution. All analyses were performed with the use of R software, version $3 \cdot 6 \cdot 3$, and

96 Rstudio, version $1 \cdot 2 \cdot 5033$ (R Foundation for Statistical Computing).

97

Table 1. Parameters considered for simulated scenarios

\begin{tabular}{|c|l|c|c|}
\hline \multirow{2}{*}{ Scenarios } & \multicolumn{3}{|c|}{ Assumptions } \\
\cline { 2 - 4 } & \multicolumn{1}{|c|}{ Hospital occupancy } & $\begin{array}{l}\text { Demand for } \\
\text { ICU beds }\end{array}$ & Public x Private Services \\
\hline 1 & $\begin{array}{l}\text { Beds, ICU beds, and ventilators } \\
\text { available for COVID-19 constrained } \\
\text { by average occupancy in 2019 }\end{array}$ & $5 \%$ of cases & $\begin{array}{l}\text { Demand for public/private services } \\
\text { apportioned by access to private health } \\
\text { insurance in 2019 }\end{array}$ \\
\hline
\end{tabular}


medRxiv preprint doi: https://doi.org/10.1101/2020.03.30.20047662; this version posted April 1, 2020. The copyright holder for this preprint (which was not certified by peer review) is the author/funder, who has granted medRxiv a license to display the preprint in perpetuity.

All rights reserved. No reuse allowed without permission.

\begin{tabular}{|c|c|c|c|}
\hline 2 & $\begin{array}{l}\text { Beds, ICU beds, and ventilators } \\
\text { available for COVID-19 constrained } \\
\text { by average occupancy in } 2019\end{array}$ & $5 \%$ of cases & $80 \%$ of the demand is for public services \\
\hline 3 & $\begin{array}{l}\text { Beds, ICU beds, and ventilators } \\
\text { available for COVID-19 constrained } \\
\text { by average occupancy in } 2019\end{array}$ & $5 \%$ of cases & $\begin{array}{l}\text { Private hospitals temporarily under the } \\
\text { control of the state }\end{array}$ \\
\hline 4 & $\begin{array}{l}\text { Beds, ICU beds, and ventilators } \\
\text { available for COVID-19 constrained } \\
\text { by average occupancy in } 2019\end{array}$ & $\begin{array}{l}12 \% \text { of } \\
\text { cases }\end{array}$ & $\begin{array}{l}\text { Demand for public/private services } \\
\text { apportioned by access to private health } \\
\text { insurance in } 2019\end{array}$ \\
\hline 5 & $\begin{array}{l}\text { Beds, ICU beds, and ventilators } \\
\text { available for COVID-19 constrained } \\
\text { by average occupancy in } 2019\end{array}$ & $\begin{array}{l}12 \% \text { of } \\
\text { cases }\end{array}$ & $80 \%$ of the demand is for public services \\
\hline 6 & $\begin{array}{l}\text { Beds, ICU beds, and ventilators } \\
\text { available for COVID-19 constrained } \\
\text { by average occupancy in } 2019\end{array}$ & $\begin{array}{l}12 \% \text { of } \\
\text { cases }\end{array}$ & $\begin{array}{l}\text { Private hospitals temporarily under the } \\
\text { control of the state }\end{array}$ \\
\hline 7 & $\begin{array}{l}2019 \text { occupancy reduced by } 50 \% \text {, and } \\
\text { services allocated to COVID-19 }\end{array}$ & $5 \%$ of cases & $\begin{array}{l}\text { Demand for public/private services } \\
\text { apportioned by access to private health } \\
\text { insurance in } 2019\end{array}$ \\
\hline 8 & $\begin{array}{l}2019 \text { occupancy reduced by } 50 \% \text {, and } \\
\text { services allocated to COVID-19 }\end{array}$ & $5 \%$ of cases & $80 \%$ of the demand is for public services \\
\hline 9 & $\begin{array}{l}2019 \text { occupancy reduced by } 50 \% \text {, and } \\
\text { services allocated to COVID-19 }\end{array}$ & $5 \%$ of cases & $\begin{array}{l}\text { Private hospitals temporarily under the } \\
\text { control of the state }\end{array}$ \\
\hline 10 & $\begin{array}{l}2019 \text { occupancy reduced by } 50 \% \text {, and } \\
\text { services allocated to COVID-19 }\end{array}$ & $\begin{array}{l}12 \% \text { of } \\
\text { cases }\end{array}$ & $\begin{array}{l}\text { Demand for public/private services } \\
\text { apportioned by access to private health } \\
\text { insurance in } 2019\end{array}$ \\
\hline 11 & $\begin{array}{l}2019 \text { occupancy reduced by } 50 \% \text {, and } \\
\text { services allocated to COVID-19 }\end{array}$ & $\begin{array}{l}12 \% \text { of } \\
\text { cases }\end{array}$ & $80 \%$ of the demand is for public services \\
\hline 12 & $\begin{array}{l}2019 \text { occupancy reduced by } 50 \% \text {, and } \\
\text { services allocated to COVID-19 }\end{array}$ & $\begin{array}{l}12 \% \text { of } \\
\text { cases }\end{array}$ & $\begin{array}{l}\text { Private hospitals temporarily under the } \\
\text { control of the state }\end{array}$ \\
\hline
\end{tabular}

\section{Results}

101 Figure 1 shows the fraction of public hospital beds and ICU beds in each health micro-region, as

102 well as the percentage of the population in those units that rely solely on the SUS. Inequities in

103 supply and demand exist, and mirror regional inequalities commonly found in social and health

104 indicators. ${ }^{9}$ 
medRxiv preprint doi: https://doi.org/10.1101/2020.03.30.20047662; this version posted April 1, 2020. The copyright holder for this preprint (which was not certified by peer review) is the author/funder, who has granted medRxiv a license to display the preprint in perpetuity.

All rights reserved. No reuse allowed without permission.

As of March 27, 3.417 cases were confirmed in Brazil, 70\% concentrated in nine cities: São

Paulo, Rio de Janeiro, Fortaleza, Brasília, Porto Alegre, Salvador, Belo Horizonte, Curitiba, and

Manaus. The growth pattern of the epidemic is not the same across the country. Therefore, we

108 chose to simulate scenarios for the nine health macro-regions associated with those cities;

109 combined these macro-regions represent $79.6 \%$ of reported cases. In the case of São Paulo and

110 Brasília, the macro-region includes only the municipality itself. Rio de Janeiro and Manaus have

111 only one macro-region for the entire state. Fortaleza, Porto Alegre, Belo Horizonte, Salvador,

112 and Curitiba are in macro-regions that comprise 44, 89, 103, 48, and 93 municipalities,

113 respectively.

114 Our simulated scenarios indicate that hospital services could start to experience shortages of

115 hospital beds, ICU beds, and ventilators across macro-regions as early as April (Figure 2). ICU

116 beds are, by far, the most pressing need. The supply of hospital beds is likely to face shortages

117 after April 21 and of mechanical ventilators just a few days afterward. The two scenarios for ICU

118 admission (5\% and $12 \%$ of the total cases) resulted in about 4-6 days difference. With a $12 \%$

119 assumption, Brasília would face a shortage of ICU beds by the end of March. Making 50\% of

120 usual occupancy dedicated to COVID-19 postpones shortages for less than a week, and placing

121 all resources under state control shifts the capacity threshold by up to one week for hospital beds

122 and mechanical ventilators, and by up to four days for ICU beds. Considering alternative

123 hypothesis of access to public resources, scenarios 2, 5, 8, and 11 assumed that $80 \%$ of the

124 demand would come from individuals that solely rely on SUS. Since the offer of SUS services

125 presents regional inequities (Figure 1), the timing of shortage depends both on the share public $\mathrm{x}$

126 private in each area. 
medRxiv preprint doi: https://doi.org/10.1101/2020.03.30.20047662; this version posted April 1, 2020. The copyright holder for this preprint (which was not certified by peer review) is the author/funder, who has granted medRxiv a license to display the preprint in perpetuity.

All rights reserved. No reuse allowed without permission.

Figure 1. Percentage of the population that relies solely on the SUS, percentage of beds available in each health macro-region that are allocated to, and location of the simulated micro-regions. Thicker black lines define the boundaries of the federal units. Selected health macro-regions are named after the capital city, and the ID code is also provided.
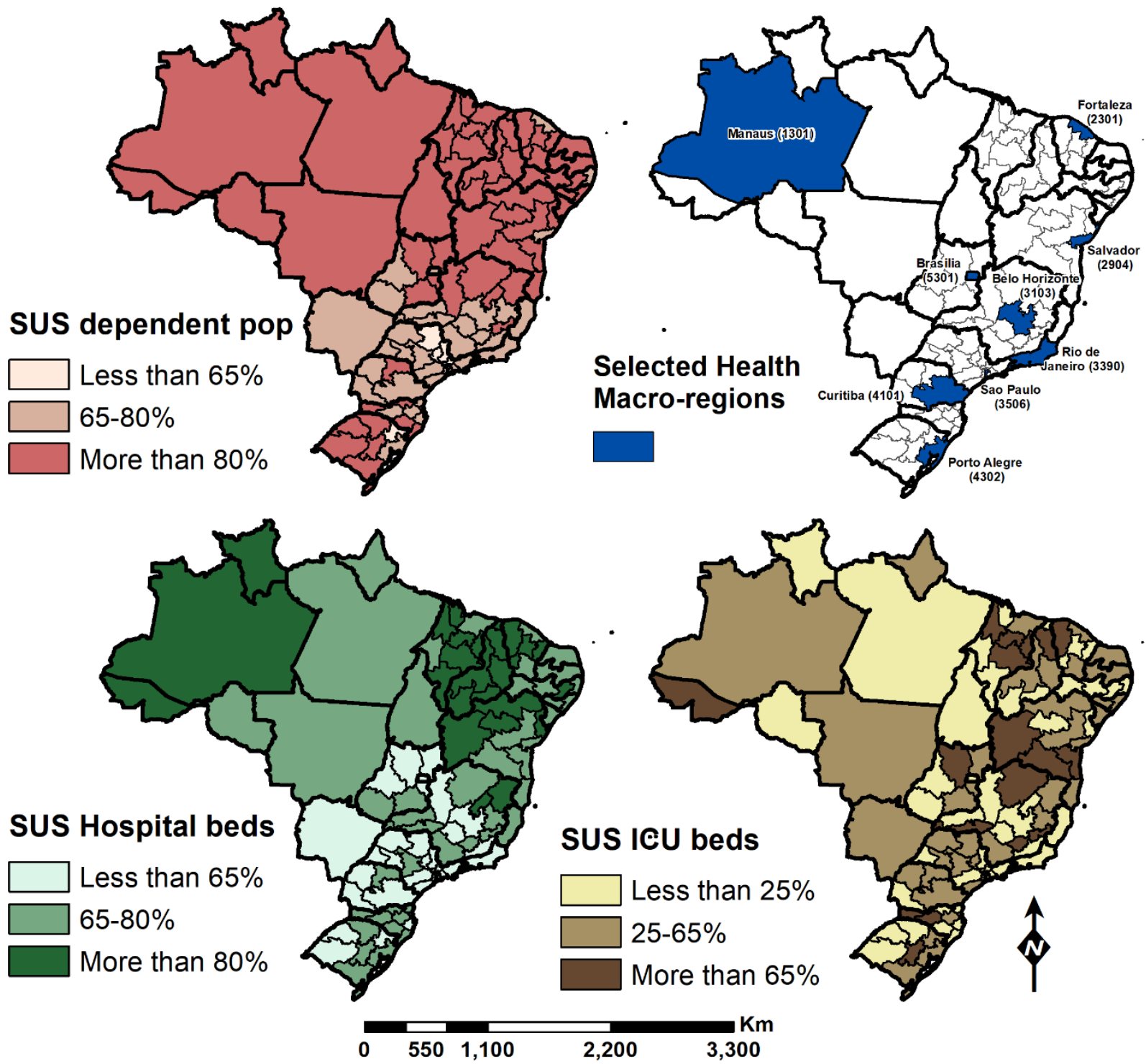

The timing of shortage varied by health macro-region. It depends on the observed onset and pace of transmission. For example, although the first case in Fortaleza was reported on March 15, 18 days after the first case was reported in the country, it took eight days to reach to 100 cases. In

137 São Paulo, where the first case was reported, the first 100 cases were recorded in 19 days. 
medRxiv preprint doi: https://doi.org/10.1101/2020.03.30.20047662; this version posted April 1, 2020. The copyright holder for this preprint (which was not certified by peer review) is the author/funder, who has granted medRxiv a license to display the preprint in perpetuity. All rights reserved. No reuse allowed without permission.

138 Figure 2. Date when hospital services will be at capacity in each simulated scenario.

139 Numbers on the left represent each of the 12 simulated scenarios described in Table1. Names on 140 top indicate the municipality of reference to the health macro-region. HB = hospital beds. ICUB $141=$ ICU beds. MV = mechanical ventilators. Numbers on the table refer to day of the month, and 142 cell colors indicate the month. Results reflect the median after 1,000 runs of the model.

143

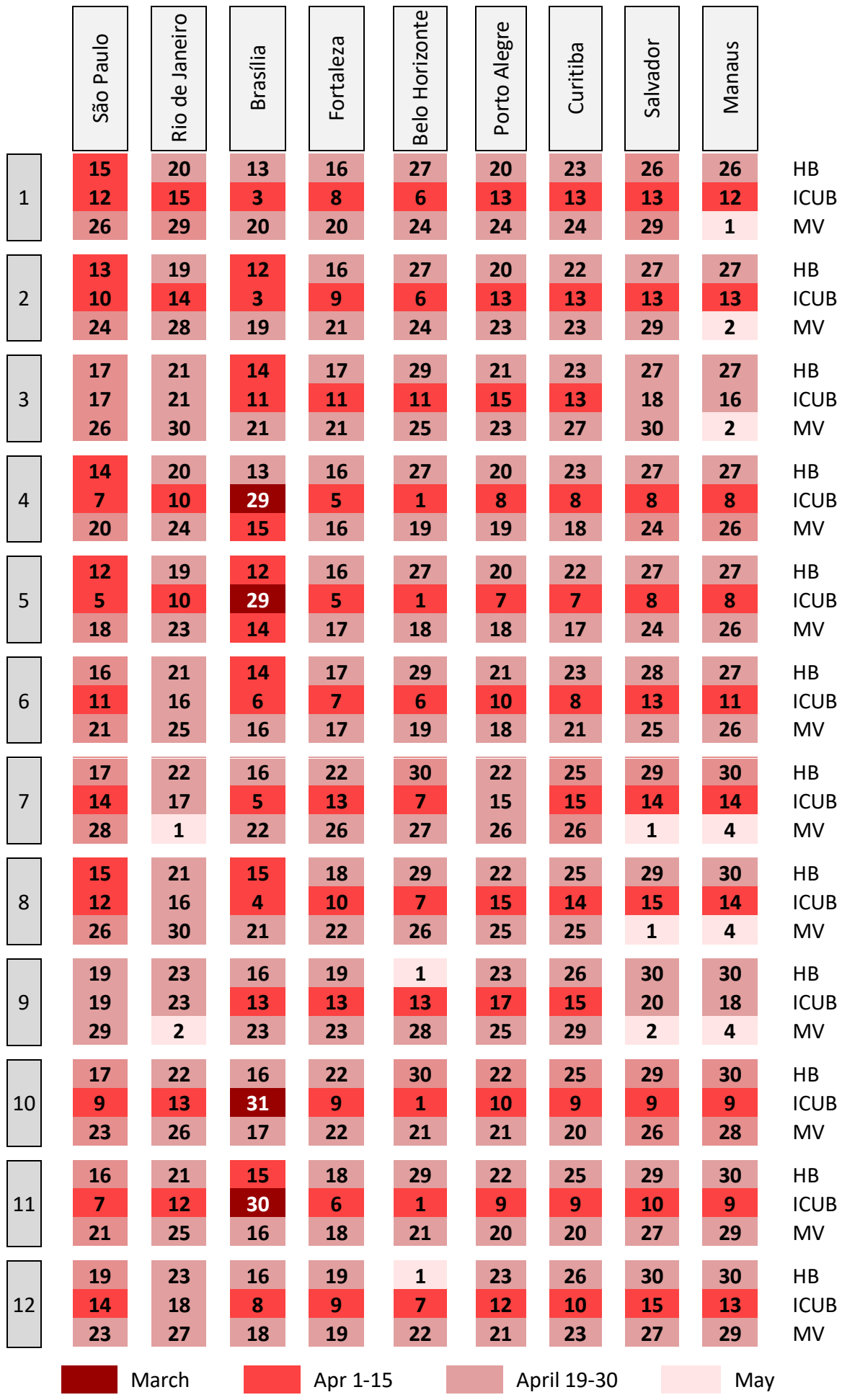


medRxiv preprint doi: https://doi.org/10.1101/2020.03.30.20047662; this version posted April 1, 2020. The copyright holder for this preprint

\section{Discussion}

146 Our simulated scenarios show that, if no change in trajectory is observed, around early April

147 Brazil would start to face shortages of hospital beds, ICU beds, and ventilators, with ICU beds

148 being the most immediate problem. The timing of shortages across the country depends on the

149 onset and the intensity of transmission. Also, the population that relies solely on SUS may bear

150 the largest burden, further exacerbating the existing inequalities, which calls for a reflection

151 around equity and ethics in service allocation. Avoiding this scenario is the paramount task of the

$152 \mathrm{MoH}$.

153 It is unreasonable to expect that all hospital resources could be entirely dedicated to COVID-19.

154 Although elective procedures can be postponed, other health emergencies compete for resources.

155 For example, dengue transmission is presently intense and increasing; until March 14 there were

156390,684 cases and 106 deaths (60.4\% of them among individuals aged 60 or more). In 2019,

157 with more than 1.5 million cases of dengue reported, $4 \%(n=55,235)$ required hospitalization.

158 Most importantly, $45 \%$ of the dengue hospitalizations occurred between March and May (21\%

159 just in May, the month when most likely the hospitals will be operating at capacity because of

160 COVID-19). In addition, the influenza season is starting, and in 2019 the peak of hospitalizations

161 occurred in May. Besides beds and ventilators, the stress imposed on the health system

162 compromises the overall care, which may result in deterioration of the treatment of other

163 conditions followed by increases in incidence. This scenario was observed during the 2013-14

164 Ebola outbreak. ${ }^{25}$

165 Shifts in the current trajectory of the epidemic in Brazil may anticipate or postpone the stress on

166 health services. Importantly, our results are sensitive to assumptions about key parameters in the 
medRxiv preprint doi: https://doi.org/10.1101/2020.03.30.20047662; this version posted April 1, 2020. The copyright holder for this preprint (which was not certified by peer review) is the author/funder, who has granted medRxiv a license to display the preprint in perpetuity.

All rights reserved. No reuse allowed without permission.

167 model, including the doubling time, underreporting rate, age-specific attack and severity rates,

168 time from illness to hospitalization and ICU, and length of stay estimates. By drawing on

169 available evidence of how COVID-19 has and is evolving across the globe, our results rely on

170 and reflect the limitations of the parameters observed in China and on unique patterns reported in

171 Italy. Given the significant uncertainty in parameter estimates at this phase of the epidemic and

172 the simplifying assumptions of an exponential model, results from our simulated scenarios

173 should not be used as precise estimates for the exact timing and extent of capacity thresholds

174 being reached. Instead, they aim to inform planning and prompt response and do send three

175 important messages.

176 First, the epidemic of COVID-19 is likely to exacerbate existing inequalities if those that solely

177 rely on the SUS are hit the hardest. In communities with high population density and poor

178 infrastructure, it is unfeasible to practice social isolation. In those areas, the transmission is likely

179 to occur fast and the population mostly relies only on the SUS, quickly overwhelming the health

180 system. One alternative to alleviate the is to temporarily put all private hospitals under the

181 control of the state, a measure adopted by Spain. ${ }^{26}$ Yet, our results show that this would postpone

182 shortages by about a week. In fact, solutions that do not involve the opening of new facilities will

183 have a very short effect on the timing of shortage.

184 Second, there is a short window of opportunity to prepare. The response must be immediate, and

185 it will demand a concerted effort from society. Repurposing large spaces (e.g., arenas,

186 convention centers) to build makeshift hospitals for additional beds is critical. Calling on the

187 industry to produce the necessary equipment (e.g., ventilators, masks, gloves, protective gown,

188 etc) and to provide it to hospitals at minimum or no cost would also contribute to mitigating the

189 stress on the system, and to safeguarding the working conditions of health care professionals. 
medRxiv preprint doi: https://doi.org/10.1101/2020.03.30.20047662; this version posted April 1, 2020. The copyright holder for this preprint (which was not certified by peer review) is the author/funder, who has granted medRxiv a license to display the preprint in perpetuity.

All rights reserved. No reuse allowed without permission.

\section{Conclusion}

Brazil is, in theory, uniquely equipped to respond to the COVID-19 epidemic. It has a free and universal health system, ${ }^{7}$ it has one of largest community-based primary care delivery programs that serves $74.8 \%$ of the population, ${ }^{28}$ it can learn from the mistakes and success that other countries hit by COVID-19 have made, and it has a history of responding to health threats by implementing governmental action and by generating high-quality scientific evidence, such as was done when Zika virus hit the country. ${ }^{29}$ Yet, the current moment is unique. It requires a unified message from the country’s leadership at various levels: federal, state, and municipal. It requires the industry to work in solidarity to produce needed inputs without aiming profit but the collective wellbeing. It requires the population to realize the importance and the urgency to comply. We hope our results will help to move forward this agenda. 
medRxiv preprint doi: https://doi.org/10.1101/2020.03.30.20047662; this version posted April 1, 2020. The copyright holder for this preprint (which was not certified by peer review) is the author/funder, who has granted medRxiv a license to display the preprint in perpetuity.

All rights reserved. No reuse allowed without permission.

\section{Contributors}

214 MCC conceived the original, was responsible for data analysis, data interpretation, data

215 visualization, and wrote the manuscript. LRC was responsible for data curation, data analysis,

216 programming, and contributed to writing. RK and TC were responsible for programming and

217 contributed to writing. GVAF, EMM, and WKO were responsible for data curation and

218 interpretation. All authors approved the final version of the manuscript.

220 References

221 1. World Health Organization. Coronavirus disease (COVID-19) outbreak situation.

222 https://www.who.int/emergencies/diseases/novel-coronavirus-2019; 2020.

223 2. Emanuel EJ, Persad G, Upshur R, et al. Fair Allocation of Scarce Medical Resources in

224 the Time of Covid-19. New England Journal of Medicine 2020.

225 3. Truog RD, Mitchell C, Daley GQ. The Toughest Triage - Allocating Ventilators in a

226 Pandemic. New England Journal of Medicine 2020.

227 4. Grasselli G, Pesenti A, Cecconi M. Critical Care Utilization for the COVID-19 Outbreak

228 in Lombardy, Italy: Early Experience and Forecast During an Emergency Response. JAMA 2020.

229 5. Tsai TC, Jacobson BH, Jha AK. American Hospital Capacity And Projected Need for

230 COVID-19 Patient Care. Health Affairs Blog 2020; (March 17. Available at:

231 https://www.healthaffairs.org/do/10.1377/hblog20200317.457910/full/).

232 6. Remuzzi A, Remuzzi G. COVID-19 and Italy: what next? The Lancet 2020; (Published

233 online March 12, 2020 https://doi.org/10.1016/S0140-6736(20)30627-9). 
medRxiv preprint doi: https://doi.org/10.1101/2020.03.30.20047662; this version posted April 1, 2020. The copyright holder for this preprint (which was not certified by peer review) is the author/funder, who has granted medRxiv a license to display the preprint in perpetuity.

All rights reserved. No reuse allowed without permission.

234 7. Castro MC, Massuda A, Almeida G, et al. Brazil's unified health system: the first 30

235 years and prospects for the future. Lancet 2019; 394(10195): 345-56.

236 8. Paim J, Travassos C, Almeida C, Bahia L, Macinko J. The Brazilian health system:

237 history, advances, and challenges. The Lancet 2011; 377(9779): 1778-97.

238 9. Menezes Filho N, Kirschbaum C. Education and Inequality in Brazil. In: Arretche M, ed.

239 Paths of Inequality in Brazil: A Half-Century of Changes. Cham: Springer International

240 Publishing; 2019: 69-88.

241 10. Carvalho LR, Andrade MV, Amaral PVM. Avaliação dos parâmetros de oferta mínimos

242 para os leitos SUS no Brasil, 2015. Planejamento e Políticas Públicas - PPP/Ipea 2020; In

243 Press.

244 11. Brasil, Ministério da Saúde. População Residente - Estudo de Estimativas Populacionais

245 por Município, Idade e Sexo 2000-2015 - Brasil. Ministério da Saúde/SVS/CGIAE.

246 http://tabnet.datasus.gov.br/cgi/deftohtm.exe?novapop/cnv/popbr.def; 2014.

247 12. Wallinga J, Lipsitch M. How generation intervals shape the relationship between growth

248 rates and reproductive numbers. Proc Biol Sci 2007; 274(1609): 599-604.

249 13. Anderson RM, May RM. Infectious Diseases of Humans: Dynamics and Control. New

250 York: Oxfor University Press Inc.; 1992.

251 14. Wu JT, Leung K, Leung GM. Nowcasting and forecasting the potential domestic and

252 international spread of the 2019-nCoV outbreak originating in Wuhan, China: a modelling study.

253 The Lancet 2020; 395(10225): 689-97.

254 15. Chinazzi M, Davis JT, Ajelli M, et al. The effect of travel restrictions on the spread of the 2552019 novel coronavirus (COVID-19) outbreak. Science 2020: eaba9757. 
medRxiv preprint doi: https://doi.org/10.1101/2020.03.30.20047662; this version posted April 1, 2020. The copyright holder for this preprint (which was not certified by peer review) is the author/funder, who has granted medRxiv a license to display the preprint in perpetuity.

All rights reserved. No reuse allowed without permission.

16. Wu JT, Leung K, Bushman M, et al. Estimating clinical severity of COVID-19 from the 257 transmission dynamics in Wuhan, China. Nature Medicine 2020.

258 17. Bi Q, Wu Y, Mei S, et al. Epidemiology and Transmission of COVID-19 in Shenzhen

259 China: Analysis of 391 cases and 1,286 of their close contacts. medRxiv 2020:

$260 \quad 2020.03 .03 .20028423$.

261 18. Li R, Pei S, Chen B, et al. Substantial undocumented infection facilitates the rapid 262 dissemination of novel coronavirus (SARS-CoV2). Science 2020: eabb3221.

263 19. Huang C, Wang Y, Li X, et al. Clinical features of patients infected with 2019 novel 264 coronavirus in Wuhan, China. The Lancet 2020; 395(10223): 497-506.

265 20. Wang D, Hu B, Hu C, et al. Clinical Characteristics of 138 Hospitalized Patients With 2662019 Novel Coronavirus-Infected Pneumonia in Wuhan, China. JAMA 2020; 323(11): 1061-9.

267 21. Guan W-j, Ni Z-y, Hu Y, et al. Clinical Characteristics of Coronavirus Disease 2019 in 268 China. New England Journal of Medicine 2020.

269 22. Zhou F, Yu T, Du R, et al. Clinical course and risk factors for mortality of adult

270 inpatients with COVID-19 in Wuhan, China: a retrospective cohort study. The Lancet 2020.

271 23. Zhou G, Chi C. A model simulation study on effects of intervention measures in Wuhan 272 COVID-19 epidemic. medRxiv 2020: 2020.02.14.20023168.

273 24. Chen J, Fan H, Zhang L, et al. Retrospective Analysis of Clinical Features in 101 Death 274 Cases with COVID-19. medRxiv 2020: 2020.03.09.20033068.

275 25. Walker PGT, White MT, Griffin JT, Reynolds A, Ferguson NM, Ghani AC. Malaria 276 morbidity and mortality in Ebola-affected countries caused by decreased health-care capacity, 277 and the potential effect of mitigation strategies: a modelling analysis. The Lancet Infectious 278 Diseases 2015; 15(7): 825-32. 
medRxiv preprint doi: https://doi.org/10.1101/2020.03.30.20047662; this version posted April 1, 2020. The copyright holder for this preprint (which was not certified by peer review) is the author/funder, who has granted medRxiv a license to display the preprint in perpetuity.

All rights reserved. No reuse allowed without permission.

279 26. Güell O, Santaeulalia I. Spanish government puts private healthcare firms at the orders of

280 the regions. El Pais. 2020 March 16, 2020.

281 27. Normile D. Coronavirus cases have dropped sharply in South Korea. What's the secret to

282 its success? Science 2020; (March 17. https://www.sciencemag.org/news/2020/03/coronavirus-

283 cases-have-dropped-sharply-south-korea-whats-secret-its-success).

284 28. Macinko J, Harris MJ. Brazil's Family Health Strategy — Delivering Community-Based

285 Primary Care in a Universal Health System. New England Journal of Medicine 2015; 372(23):

$286 \quad 2177-81$.

287 29. (Editorial). Zika must remain a high priority. Nature 2016; 533(7603): 291. 